\title{
The Relationship Between Thyroid Functions with Nutritional Status and Blood Pressure in the Women of Child Bearing Age
}

\author{
Suryati Kumorowulan ${ }^{1}$, Yusi DN ${ }^{1}$, Ina Kusrini ${ }^{1}$, Hastin DK ${ }^{1}$, Ernani Budi ${ }^{1}$, Nur \\ Asiyatul Janah ${ }^{1}$
}

${ }^{I}$ Balai Litbang Kesehatan Magelang, Magelang, Indonesia

*Corresponding author: Suryatiyk@yahoo.co.id

\begin{abstract}
Currently non-communicable diseases occupy the highest position in Indonesia. Hypertension and cardiovascular disease still occupy the top ten diseases. Non-communicable diseases also include thyroid dysfunction where hyperthyroidism can cause cardiovascular disorders. Patients with thyroid disease, especially hyperthyroidism, often show signs and symptoms of cardiovascular changes. On the other hand, thyroid dysfunction can cause changes in nutritional status and metabolic disorders. The incidence of hypertension is often associated by cigarette exposure. The objective of this study was to assess the relationship between thyroid function and nutritional status and blood pressure in Women of child bearing age in three areas with varying iodine status. Method. This research is Cross-sectional study on Women of child bearing age in three areas with varying degrees of iodine status, namely Yogyakarta City, Bukit Tinggi City and Purworejo districts. The sample size of each area is 160 subjects, with total subjects are 480 Women of child bearing age. Nutritional status, blood pressure, iodine salt, urinary iodine excretion (UIE), fT4 and TSH levels were measured in the subjects. History of cigarettes exposure was also collected. Analysis of variance and multivariate regression was performed to analyze the relationship between thyroid function and nutritional status and blood pressure. Results. There were significant differences between regions in the nutritional status / BMI variables, iodine salt levels, UIE, fT4 and TSH levels. Median UIE in Yogyakarta city is $220 \mu \mathrm{g} / \mathrm{ml}$ (more than normal), in Bukit Tinggi city is $85 \mu \mathrm{g} / \mathrm{ml}$ (deficiency) and median UIE in Purworejo is $225 \mu \mathrm{g} / \mathrm{ml}$ (more than normal). Majority of thyroid function in three areas is normal. There was a significant relationship between BMI and thyroid function (fT4) after controlling for age and a history of iodine adequacy $(\beta=-0.132, p=0.005)$. There was a significant relationship between systolic blood pressure and thyroid function (fT4) after accounting for BMI, age and a history of iodine adequacy $(\beta=0.117, \mathrm{p}=$ 0.009). There is no relationship between diastolic blood pressure and thyroid function and there is no relationship between blood pressure with history of cigarettes exposure. Conclusion. There is a significant relationship between BMI and thyroid function and there is a significant relationship between systole blood pressure and thyroid function. Recommendation. Prevention and management of non-communicable diseases must be comprehensive because the non-communicable diseases are related to one another.
\end{abstract}

Keywords: UIE, TSH, fT4, BMI

\section{INTRODUCTION}

Non-communicable diseases (PTM) in Indonesia currently occupy the top ten diseases, and are the leading cause of death in the world and in Indonesia. The results of the Basic Health Research (RISKESDAS) in 2018 stated that noncommunicable diseases in Indonesia increased compared to 2013, and also in 2007 the number of patients with cancer, stroke, chronic kidney disease, diabetes, and hypertension increased significantly, if compared to the results of RISKESDAS in the year 2013 [1,2,3].
The results of blood pressure measurements showed the prevalence of hypertension rose from $25.8 \%$ to $34.1 \%$. The increase in the prevalence of non-communicable diseases is associated with changes in lifestyle such as an increase in the number of smokers, an increase in alcohol consumption, lack of physical activity, and a lack of consumption of fruits and vegetables.

Lack of physical activity and lack of consumption of vegetables and fruit can trigger changes in nutritional status such as increased obesity. Increased obesity can be a trigger or a risk factor for Diabetes Mellitus, Hypertension and other metabolic diseases. Metabolic disorders due to unhealthy 
consumption patterns can also be affected by hormonal imbalances, one of which is due to thyroid dysfunction. Impaired thyroid function can be caused due to deficiency or excess of iodine which will has implications for the rise and fall of Thyroid Releasing Hormones and thyroid hormones so that hypothyroid or hyperthyroid conditions arise [4]. Noncommunicable diseases can be related to one another or can affect each other, so prevention and handling must be comprehensive. Therefore this study wants to see the relationship between non-communicable diseases with variables that can affect non communicable disease.

\section{METHOD}

This study is a cross sectional study with a sample of Women of Child Bearing Age (CBW), 15 to 45 years, research sites in Yogyakarta City, Purworejo Regency and in Bukit Tinggi City and these three places represent different levels of iodine sufficiency. There are 160 sample sizes in each place so that the total sample is 480 . Variables measured including body weight, height, blood pressure, iodine salt level measurements with rapid tests and titrations, while determining the level of adequacy or iodine status in the community by measuring iodine levels in urine (UIE) are using the Spectrophotometry method. This study also measured thyroid function by measuring TSH and FT4 levels using the ELIZA method. Data on the history of cigarette exposure were also collected.

\section{RESULTS AND DISCUSSION}

The results of the study in Yogyakarta City, Bukittinggi City and Purworejo Regency are shown in the table and figure below: Table 1 shows that the average age of subjects ranged from 33 to 36 years, including the group of women of childbearing age. Statistical tests show there is no age difference between groups. Based on the measurement results, the mean body weight and height of the subjects were $57.7 \pm$ 11.83 kilograms and $151.9 \pm 5.43 \mathrm{~cm}$ with a Body Mass Index (BMI) value approaching the excess nutritional limit of $25.0 \pm$ 4.85. The description of iodine levels in salt by the titration method can be seen in Figure 1 below:

Table 1. Comparison of Characteristics and Biochemical Parameters of Fertile Age Women in Cities Yogyakarta, Bukit Tinggi City and Purworejo Districts

\begin{tabular}{|c|c|c|c|}
\hline & $\begin{array}{l}\text { Yogyakarta } \\
\text { City } \\
(\mathrm{N}=160) \\
(\text { Ref })\end{array}$ & $\begin{array}{l}\text { BukitTinggi } \\
\text { City } \\
(\mathrm{N}=160)\end{array}$ & $\begin{array}{l}\text { Purworejo } \\
\text { districts } \\
(\mathrm{N}=160)\end{array}$ \\
\hline \multicolumn{4}{|l|}{$\begin{array}{l}\text { Characteristics of } \\
\text { Subject }\end{array}$} \\
\hline Age, Mean \pm SD & $35,5 \pm 8,77$ & $34,3 \pm 7,76$ & $33,7 \pm 8,73$ \\
\hline $\begin{array}{l}\text { weight, } \\
\text { Mean } \pm S D, K g \#\end{array}$ & $\begin{array}{l}59,2 \\
12,89\end{array}$ & $\begin{array}{l}59,6 \quad \pm \\
11,52\end{array}$ & $54,3 \pm 10,26^{\mathrm{a}}$ \\
\hline $\begin{array}{l}\text { height, } \\
\text { mean } \pm \mathrm{SD}, \mathrm{cm}\end{array}$ & $\begin{array}{l}152,6 \quad \pm \\
5,76\end{array}$ & $\begin{array}{l}151,8 \quad \pm \\
5,59\end{array}$ & $151,4 \pm 4,88$ \\
\hline $\begin{aligned} & \text { BMI, mean } \\
\pm \text { SD\# } & \end{aligned}$ & $25,4 \pm 5,13$ & $25,9 \pm 4,86$ & $23,7 \pm 4,26^{\mathrm{a}}$ \\
\hline $\begin{aligned} \text { Salt } & \text { Iodine } \\
\text { levels, } & \end{aligned}$ & $\begin{array}{l}39,4 \quad(0,00- \\
218,23)\end{array}$ & $\begin{array}{l}39,4 \quad(0,00- \\
184,44)\end{array}$ & $\begin{array}{l}35,7 \\
175,22)^{\mathrm{c}}\end{array} \quad(0,82-$ \\
\hline
\end{tabular}

\begin{tabular}{|c|c|c|c|}
\hline $\begin{array}{c}\text { (med, min-max), } \\
\mu \mathrm{g} / \mathrm{L}^{*}\end{array}$ & & & \\
\hline $\begin{array}{rr}\text { Salt } & \text { Iodine } \\
\text { levels, } & \text { mean } \pm S D, \\
\mu \mathrm{g} / \mathrm{L}^{*} & \end{array}$ & $\begin{array}{ll}43,3 & \pm \\
25,13 & \end{array}$ & $\begin{array}{ll}41,1 & \pm \\
25,85 & \end{array}$ & $36,6 \pm 18,50$ \\
\hline $\begin{array}{l}\text { Systole, } \\
\text { mean } \pm \text { SD, mmHg }\end{array}$ & $\begin{array}{l}124,1 \\
19,11\end{array}$ & $\begin{array}{l}124,1 \\
16,20\end{array} \quad \pm$ & $122,5 \pm 14,81$ \\
\hline $\begin{array}{l}\text { Dyastole, } \\
\text { mean } \pm \mathrm{SD}, \mathrm{mmHg}\end{array}$ & $\begin{array}{ll}78,1 & \pm \\
12,24 & \end{array}$ & $\begin{array}{ll}77,4 & \pm \\
10,43 & \end{array}$ & $76,6 \pm 10,22$ \\
\hline \multicolumn{4}{|l|}{$\begin{array}{l}\text { Exposured to } \\
\text { cigarette smoke, } N \\
(\%)^{\$}\end{array}$} \\
\hline Yes & $57(35,6)$ & $19(11,9)$ & $15(9,4)$ \\
\hline No & $103(64,4)$ & $141(88,1)$ & $145(90,6)$ \\
\hline \multicolumn{4}{|l|}{$\begin{array}{l}\text { Biocemitry of } \\
\text { Subject }\end{array}$} \\
\hline $\begin{array}{l}\text { Urin Iodine Level } \\
\text { (med, min-maks), } \\
\mu \mathrm{g} / \mathrm{L}^{*}\end{array}$ & $\begin{array}{l}219 \\
582)\end{array}$ & $85(4-495)^{\mathrm{b}}$ & $224(33-1320)^{\mathrm{c}}$ \\
\hline $\begin{array}{l}\text { Urin Iodine Level } \\
\text { mean } \pm S D, \mu \mathrm{g} / \mathrm{L}^{*}\end{array}$ & $\begin{array}{ll}225,7 & \pm \\
104,78 & \end{array}$ & $\begin{array}{l}108,7 \\
80,28\end{array}$ & $244,3 \pm 143,32$ \\
\hline $\begin{array}{l}\mathrm{fT} 4, \quad(\text { median, } \\
\text { min-maks), ng/L* }\end{array}$ & $\begin{array}{l}1,1(0,63- \\
3,34)\end{array}$ & $\begin{array}{l}1,2(0,10- \\
2,77)^{\mathrm{b}}\end{array}$ & $1,4(0,82-2,09)^{\mathrm{c}}$ \\
\hline $\begin{array}{c}\mathrm{fT} 4, \quad \text { mean } \pm \mathrm{SD}, \\
\mathrm{ng} / \mathrm{L}\end{array}$ & $1,1 \pm 0,26$ & $1,2 \pm 0,27$ & $1,3 \pm 0,23$ \\
\hline $\begin{array}{l}\text { TSH, (median, } \\
\text { min-maks), } \\
\mu \mathrm{IU} / \mathrm{ml}^{*}\end{array}$ & $\begin{array}{l}1.9(0,01- \\
9,44)\end{array}$ & $\begin{array}{l}1,9 \quad(0,06- \\
31,05)\end{array}$ & $1,6(0,03-9,54)^{\mathrm{c}}$ \\
\hline $\begin{array}{l}\text { TSH, mean } \pm \text { SD, } \\
\mu \mathrm{IU} / \mathrm{ml}\end{array}$ & $2,3 \pm 1,83$ & $2,3 \pm 2,64$ & $1,8 \pm 1,36$ \\
\hline
\end{tabular}

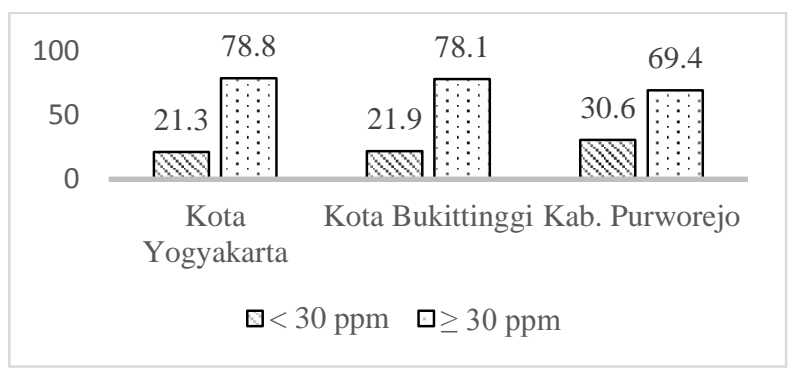

Figure 1. Results of measurements of iodine levels in salt by the tritation method

Figure 1 shows that the use of iodized salt still uses salt with levels less than $30 \mathrm{ppm}$. The description of nutritional status in $\mathrm{CBW}$ in the three regions is shown in Figure 2. 
above $200 \mu \mathrm{g} / \mathrm{L}$. The description of thyroid function based on TSH and FT4 values can be seen in Figure 5 below:

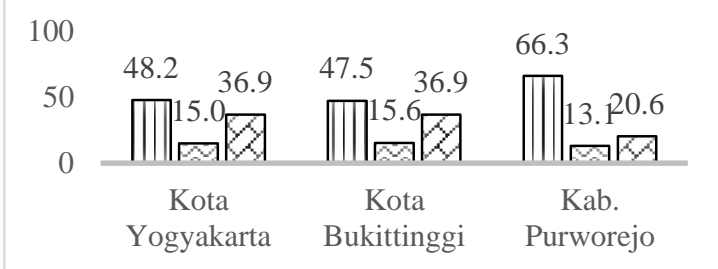

Figure 2. presents an overview of nutritional status in Yogyakarta City, Bukittinggi City, and Purworejo District.

The nutritional status of subjects was divided into normal with a BMI <18.5 - 25.0 and an excess nutritional status with a BMI> 25.1. Most of the nutritional status in the three regions is normal and the obese nutritional status in Yogyakarta and Bukittinggi is the same, $36.9 \%$. As for the description of hypertension in the three regions shown in Figure 3.

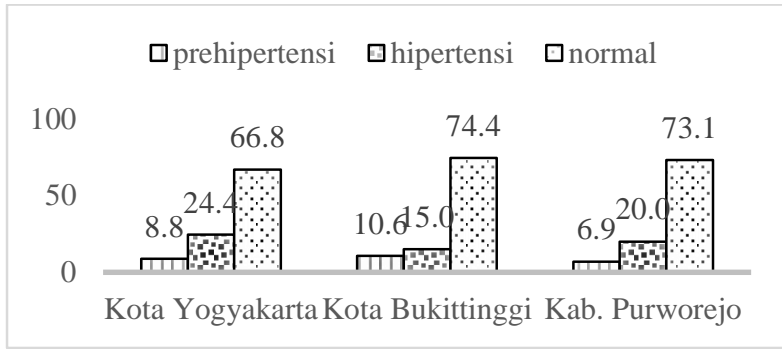

Figure 3. Overview of blood pressure in CBW in Yogyakarta City, Bukittinggi City, Purworejo Regency

Based on the results of blood pressure measurements showed that most of the systolic and diastolic blood pressure in the three groups was normal and there were no significant differences between the three regions. While the description of iodine status seen from UIE in the three regions can be seen in Figure 4.

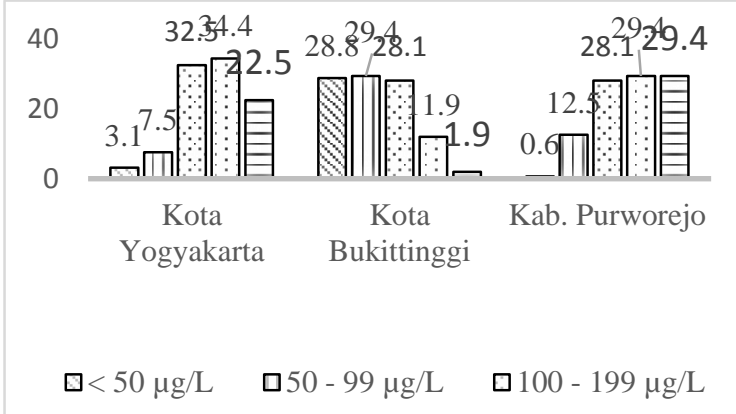

Figure 4. UIE levels in CBW in Yogyakarta City, Bukittinggi City and Purworejo District

Figure 4 shows that the proportion of iodine levels in urine (UIE) in Yogyakarta City is at most levels above normal 200 $299 \mu \mathrm{g} / \mathrm{L}$ (34.4\%), whereas in Bukittinggi the highest proportion of IUE levels is at 50 - $99 \mu \mathrm{g}$ levels / L (29.4\%) and Purworejo Regency the majority proportion of UIE levels was

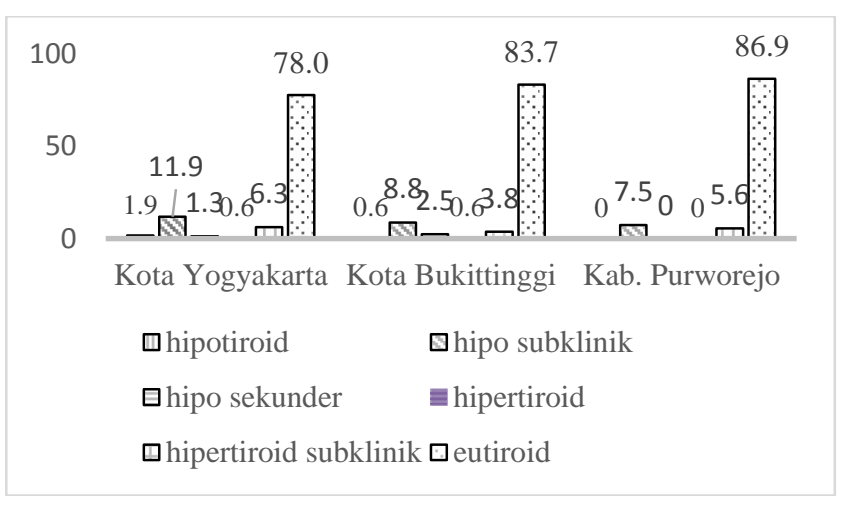

Figure 5. Description of Thyroid Function based on TSH and FT4 levels in CBW in Yogyakarta City, Bukittinggi City and Purworejo District

Figure 5 shows thyroid function based on TSH and FT4 levels in both Yogyakarta City, Bukittinggi City and Purworejo District, which are mostly normal or euthyroid. As for seeing how the relationships between variables namely nutritional status, blood pressure and thyroid function and iodine status are shown in table 2 .

Table 2. Results of Multiple Regression Analysis between Thyroid Hormone with Nutritional Status, Systolic Blood Pressure and Diastole after Considering Age and Iodine Status

\begin{tabular}{|c|c|c|c|c|c|}
\hline $\begin{array}{l}\text { Variable } \\
\text { dependent }\end{array}$ & $\begin{array}{l}\text { Variable } \\
\text { independent }\end{array}$ & $\beta$ & $\mathrm{P}$ & $r^{2}$ & $\mathrm{p}$ \\
\hline \multirow[t]{5}{*}{ BMI } & TSH & & & & \\
\hline & & 0,053 & 0,255 & 0,065 & 0,000 \\
\hline & fT4 & $0, \overline{132}$ & 0,005 & & \\
\hline & Age & 0,214 & 0,000 & & \\
\hline & $\begin{array}{l}\text { Status } \\
\text { iodine }\end{array}$ & $-\overline{0}, 086$ & 0,060 & & \\
\hline \multirow[t]{5}{*}{ Systole } & TSH & 0,010 & 0,826 & 0,185 & 0,000 \\
\hline & fT4 & 0,117 & 0,009 & & \\
\hline & Age & 0,290 & 0,000 & & \\
\hline & BMI & 0,269 & 0,000 & & \\
\hline & $\begin{array}{l}\text { Status } \\
\text { iodine }\end{array}$ & 0,002 & 0,961 & & \\
\hline \multirow[t]{5}{*}{ Dyastole } & TSH & 0,002 & 0,974 & 0,121 & 0,000 \\
\hline & fT4 & 0,062 & 0,180 & & \\
\hline & Age & 0,153 & 0,000 & & \\
\hline & BMI & 0,299 & 0,000 & & \\
\hline & $\begin{array}{l}\text { Status } \\
\text { iodine }\end{array}$ & 0,026 & 0,560 & & \\
\hline
\end{tabular}

Multiple regression tests showed that there was a significant negative relationship between BMI and thyroid function (fT4) after accounting for age and iodine status $(\beta=-0.132, \mathrm{p}=$ 0.005). Thyroid function (fT4) is positively related 
significantly to systole blood pressure after calculating age, nutritional status and iodine status $(\beta=0.117, \mathrm{p}=0.009)$. Whereas diastolic blood pressure has no significant relationship with thyroid function. The results of this study indicate that the status of excess nutrition and obesity is more than $50 \%$, and the results of Riskesdas 2018 show that the percentage of over nutrition and obesity has increased compared to Riskesdas in 2013. Increasing prevalence of obesity will have an impact on increasing metabolic syndrome and non-communicable diseases such as DM, Hypertension, and stroke $[2,3]$.

This study also looked at some aspects of using iodized salt at the Household level and the results of the salt inspection using the titration method showed that at the household level in the city of Yogyakarta, Bukittinggi City and Purworejo Regency the iodine salt level was above $30 \mathrm{ppm}$. Universal Salt Iodization with iodized salt is a sign of the success of programs in various countries with a goal of more than $90 \%$ of households using iodized salt. ${ }^{5}$ Iodized salt is one source of iodine that enters the body. This iodine is needed to form thyroid hormone [6].

This study also looked at iodine status or iodine adequacy in Fertile Age Women viewed from urine iodine (UIE) levels. Indicators of iodine adequacy or iodine status can be seen from urine iodine levels or UIE. Iodine levels in urine describe daily iodine intake. Classification of iodine status in the population can be seen from the median urine iodine level [7,8]. Median Iodine Urine in Yogyakarta City shows a value of $219 \mu \mathrm{g} / \mathrm{L}$ means that the iodine status is above normal, the normal median UIE value is $100-199 \mu \mathrm{g} / \mathrm{L}$, as well as for Purworejo district the median urine iodine level is $224 \mu \mathrm{g} / \mathrm{L}$ (more than normal), but on the contrary in Kota Tinggi the median urine iodine level is only $85 \mu \mathrm{g} / \mathrm{L}$ meaning it is still less than normal or mild iodine deficiency. Iodine deficiency is still a health problem in Bukit Tinggi City because the proportion of UIE that is less than $50 \mu \mathrm{g} / \mathrm{L}$ is $29.4 \%$ whereas the WHO standard for those less than $50 \mu \mathrm{g} / \mathrm{L}$ must be less than $20 \%$ [5]. The results of this study also showed that the prevalence of hypertension in Yogyakarta City, Bukittinggi City and Purworejo District was still lower than the national figure of $25.8 \%$ in 2013 and nationally increased to $34.1 \%$ in 2018 .

Hypertension is a condition where blood pressure chronically increased blood vessels, due to among others the heart works harder to pump blood to meet the body's oxygen and nutritional needs. Hypertension criteria used refers to the diagnostic criteria for JNC VII 2003, which are the results of systolic blood pressure measurement $\geq 140 \mathrm{mmHg}$ or diastolic blood pressure $\geq 90 \mathrm{mmHg}$ [9]. Prehypertensive criteria refer to clinical diagnosis criteria in metabolic syndrome where systolic blood pressure $\geq 130 \mathrm{~mm} \mathrm{Hg}$ and or diastolic blood pressure $\geq 85 \mathrm{~mm} \mathrm{Hg}$.

Hypertension is divided into 2 groups based on the cause, namely: Essential hypertension and secondary hypertension or renal hypertension. Essential hypertension is not known why and is $90-95 \%$ of cases of hypertension. Some factors that influence the incidence of essential hypertension including sodium consumption, age, genetics, stress, obesity or obesity, lifestyle, alcohol and smoking. Because essential hypertension is the largest group of hypertension, management and treatment are more aimed at essential hypertension [10-12]. Secondary hypertension causes including renal vascular abnormalities, diabetes, adrenal gland disease, and thyroid dysfunction (hyperthyroidism) [10,13]. In this study there is a relationship between thyroid function and systole blood pressure.

Statistical analysis showed that there was a relationship between nutritional status in CBW and thyroid function. Thyroid function is measured based on TSH and FreeT4 (thyroid hormone) levels. Thyroid hormones affect all metabolic pathways in the body, and have an important role in metabolic processes [14]. These hormones increase basal energy expenditure from the metabolism of carbohydrates, proteins, fats. ${ }^{15}$, deficiency or excess thyroid hormones that can interfere with physiological processes including nutrient metabolism. ${ }^{16}$ The combination of TSH and FreeT4 levels can be used to see thyroid function whether hypothyroid, euthyroid or hyperthyroid.

\section{CONCLUSION}

There is a significant negative relationship between BMI and thyroid function (fT4) after accounting for age and iodine status $(\beta=-0.132, \mathrm{p}=0.005)$. There is a significant positive relationship between thyroid function (fT4) and systole blood pressure after calculating age, nutritional status and iodine status $(\beta=0.117, \mathrm{p}=0.009)$. There is no significant relationship between diastolic blood pressure and thyroid function.

\section{REFERENCES}

[1] Badan Litbang Kesehatan Kementrian Kesehatan Republik Indonesia.2007. Laporan RISKESDAS 2007. Badan Litbang Kesehatan, Jakarta

[2] Badan Litbang Kesehatan Kementrian Kesehatan Republik Indonesia.2007. Laporan RISKESDAS 2013. Badan Litbang Kesehatan, Jakarta

[3] Badan Litbang Kesehatan Kementrian Kesehatan Republik Indonesia.2007. Laporan RISKESDAS 2018. Badan Litbang Kesehatan, Jakarta

[4] Gardner, David G dan Shoback, Dolores. 2011. Greenspan's Basic and Clinical Endocrinology $9^{\text {th }}$ edition. Lange Mc.Gaw Hill.China

[5] WHO, UNICEF, ICCIDD. 2007. Assessment of the Iodine Deficiency Disorders and Monitoring Their Elimination. $2^{\text {nd }}$ edition. Geneva:WHO

[6] Dunn, JT and Dunn AD. 2001. Update on Intrathyroidal Iodine Metabolism. Thyroid $11: 407$.

[7] Zimmermann M. B. 2009. Iodine Deficiency. Endocrine Reviews, 30(4), 376-408. doi:10.1210/er.2009-0011

[8] Zimmermann M. B., Jooste P. L., Pandav C. S. 2008. Iodine deficiency disorders. Lancet, 372, 1251-1262. doi:10.1016/S0140-6736(08)61005-3

[9] Muhadi. Evidence-based Guideline (Penanganan pasien hipertensi dewasa). JNC 8. 2016;43:CKD 236.

[10] Al Disi SS, Anwar MA, Eid AH. Anti-hypertensive herbs and their mechanisms of action: part I. Frontiers in pharmacology. 2016;6:323.

[11] Sibai BM. Etiology and management of postpartum hypertension-preeclampsia. American journal of obstetrics and gynecology. 2012;206(6):470-5 . 
Hyphertiroidism and Hyphotiroidism, Endocrine

[12] Degnan I. Vascular etiology of intracranial hypertension. Kaohsiung journal of medical sciences. 2016;32:389e90.

[13] Singh S. Etiology and management of hypertension in chronic kidney disease. Clinical Queries: Nephrology. 2012;1(4):259-67.

[14] AACE. 2002. Medical Guidelines for Clinical Practise for The Evaluation and Treatment of
Practise, Vol 8. No. 6 Nov/Dec 2002.

[15] Pucci, E dkk. 2000. Thyroid and Lipid Metabolism. Int.J Obes Relat Metab Disord 24 Suppl 2: S109-12

[16] Klein, I.2001. Clinical, Metabolic, and Organ Spesific Indices of Thyroid Function. Endocrinal Metab Clin North Am 30:415 